Article

\title{
Environmental Impact Assessment of Potentially Toxic Elements in Soils Near the Runway at the International Airport in Central Europe
}

\author{
Martin Brtnický ${ }^{1,2,3, *}$, Václav Pecina ${ }^{1,2}$, Tivadar Baltazár ${ }^{2}{ }^{5}$, Michaela Vašinová Galiová ${ }^{1}$, \\ Ludmila Baláková ${ }^{3}$, Agnieszka Bęś ${ }^{4}$ (D) and Maja Radziemska ${ }^{5, *(D)}$ \\ 1 Institute of Chemistry and Technology of Environmental Protection, Faculty of Chemistry, \\ Brno University of Technology, Purkyňova 118, 61200 Brno, Czech Republic; \\ vaclav.pecina@mendelu.cz (V.P.); galiova@fch.vut.cz (M.V.G.) \\ 2 Department of Agrochemistry, Soil Science, Microbiology and Plant Nutrition, Faculty of AgriSciences, \\ Mendel University in Brno, Zemědělská 1, 61300 Brno, Czech Republic; tivadar.baltazar@mendelu.cz \\ 3 Department of Geology and Pedology, Faculty of Forestry and Wood Technology, Mendel University in Brno, \\ Zemědělská 3, 61300 Brno, Czech Republic; ludmila.balakova@mendelu.cz \\ 4 Faculty of Environmental Management and Agriculture, University of Warmia and Mazury in Olsztyn, \\ Pl. Łódzki 4, 10-727 Olsztyn, Poland; agnieszka.bes@uwm.edu.pl \\ 5 Institute of Environmental Engineering, Warsaw University of Life Sciences, 159 Nowoursynowska, \\ 02-776 Warsaw, Poland \\ * Correspondence: Martin.Brtnicky@seznam.cz (M.B.); maja_radziemska@sggw.edu.pl (M.R.); \\ Tel.: +48-2259-353-70 (M.R.)
}

Received: 17 August 2020; Accepted: 29 August 2020; Published: 3 September 2020

check for updates

\begin{abstract}
The environmental impacts of air transport and air transportation systems have become increasingly important and are heavily debated. The aim of the study was to determine the degree of soil contamination by the potentially toxic elements $(\mathrm{Cu}, \mathrm{Ni}, \mathrm{Pb}$, and $\mathrm{Zn})$ in the vicinity of the airport runway and to evaluate whether airport traffic has had factual toxic effects on airport vegetation. The overall assessment of soil contamination by means of the Nemerow integrated pollution index indicated slight pollution; evaluation by the geoaccumulation index evinced moderate contamination by $\mathrm{Zn}$ and nonexistent to moderate contamination by $\mathrm{Cu}, \mathrm{Ni}$, and $\mathrm{Pb}$. A significant difference between the take-off and landing sections of the runway was not statistically confirmed. The vegetation risk assessment by means of the potential ecological risk index (RI) showed the low ecological risk, while the phytotoxicity test revealed an inhibition of up to $33.7 \%$, with a slight inhibition of $16.7 \%$ on average, and thus low toxic effects of airport traffic on airport vegetation. The results of the linear regression model between phytotoxicity and RI manifested no relation between the two. The outcomes from other studies suggest that the range of elements and the extent of contamination can be highly variable at different airports and frequently affected by car traffic. Therefore, further research on this issue is needed for the more precise determination of the elements emitted by air traffic at airports.
\end{abstract}

Keywords: air transport; soil contamination; ecological risk assessment; eco-toxicology study; phytotoxicity

\section{Introduction}

Among the broad spectrum of human activities that may have an impact on the degradation of the natural environment, transportation activity holds a significant position [1,2]. This degradation may pertain to various components of the environment to different degrees (air, water, and soil), along with its landscape values. Air transportation is an important part of the economy and quality of life through the promotion of trade and tourism on a global scale [3-5]. Its importance is constantly growing [6]. 
For instance, civil aviation is fast-growing, with about $+5 \%$ growth every year, driven mainly by globalization and developing economies [7]. Currently, passenger flights comprise approximately $10 \%$ of total worldwide passenger traffic, while transportation services via airplanes cover approximately $35 \%$ of demand for cargo transport [3]. Air travel/traffic brings many social and economic benefits $[4,5,8]$, not merely for people involved in the aviation industry, but also for local economies around the airports [9]. However, due to the existing large and still growing scale of air transport and the air transportation system, their undesirable environmental impacts have become increasingly important, and therefore they are heavily debated $[3,7,10,11]$.

Means of air transport may affect individual components of the natural environment on many levels [12]. Air transportation may impact the health of people and other living organisms not only at the local level with the great potential risk, seeing as how most large airports are located near heavily populated urban settlements [7], but also at a regional level or on a global scale. Most negative effects are perceived in the direct surrounding of airports, though air traffic may also influence climate changes on regional and global scales [13]. The impact at the local level is mainly associated with noise and air pollution in the vicinity of airports $[5,11,14]$. Nevertheless, soil contamination by potentially toxic elements (PTEs) can also represent a problem [15-17]. PTEs are one of the most serious environmental hazards due to their toxicity, persistence, and bioaccumulation threatening the health of all living systems [18-20]. Air pollution may also be a problem at the regional level and on a global scale, possibly resulting in climate change as aviation is an important source of $\mathrm{CO}_{2}$ emissions $[3,5,9]$.

Airport sources of pollution are not limited to only aircraft engine exhaust and non-exhaust emissions, but also, for example, emissions from the traffic due to the airport ground service, the units providing power to the aircraft on the ground, building emissions, maintenance work, and fugitive vapors from refueling operations $[7,10,15]$. Despite the increased attention given to environmental impacts of air transportation and its emissions at the ground-level and air pollution near airports, many research gaps still remain [7].

Although there is a lamentable lack of relevant studies in the scientific literature on soil pollution at airports and its effects on ecosystems, one recent study pointed to a possible moderate potential risk to living systems by means of potential ecological risk assessment [21]. The aim of this study was to determine whether airport operations have factual toxic effects on airport vegetation. This goal was achieved in several partial steps: (1) by determining the contents of PTEs $(\mathrm{Cu}, \mathrm{Ni}, \mathrm{Pb}$, and $\mathrm{Zn})$ in the vicinity of the airport runway, (2) calculating indices assessing the level of contamination and environmental risk, (3) determining the phytotoxicity of the soils in the vicinity of the airport runway, and (4) comparing the level of contamination and the environmental risk with phytotoxicity and discussing other possible sources of risk.

\section{Materials and Methods}

\subsection{Study Area}

Warsaw Chopin Airport (also known as Okęcie Airport) was opened in 1934 [22] and is currently the biggest airport in Poland with an area of approximately $6,800,000 \mathrm{~m}^{2}$. It has two intersecting runways $(3690 \times 60 \mathrm{~m} ; 2800 \times 50 \mathrm{~m})$ with an asphalt surface and the capacity for 35 aircraft operations per hour [4]. It is a busy airport with approximately 17.7 million passengers annually (2018) and their amount is continuously growing [22]. Passenger operations constitute approximately $86 \%$ of all the aircraft movements at the airport. The Chopin Airport was built on a former military airfield and is currently a city airport, located just $8 \mathrm{~km}$ from the city center [4]. The area lies in the continental humid climate zone according to the classification by Köppen-Geiger. The characteristic feature of the climate is precipitation with a many-year average of approximately $550 \mathrm{~mm} /$ year, with the maximum in July $(75 \mathrm{~mm})$ and minimum in February $(20 \mathrm{~mm})$. The average yearly temperature is $8.2^{\circ} \mathrm{C}$, with the maximum in July $\left(18.3^{\circ} \mathrm{C}\right)$ and minimum in January $\left(-2.2^{\circ} \mathrm{C}\right)$. The area is most frequently under the 
influence of polar maritime air masses (approximately $60 \%$ of the days in a year) as well as polar continental (approximately $30 \%$ of days in a year) [Okęcie station $\left(\varphi=52^{\circ} 09^{\prime} \mathrm{N}, \lambda=20^{\circ} 59^{\prime} \mathrm{E}, \mathrm{H}=106 \mathrm{~m}\right.$ a.s.l.)].

\subsection{Soil Sampling and Processing}

The longer runway $(3690 \times 60 \mathrm{~m})$, running in the NNW-SSE direction, is used for both take-offs and landings, however, with a preference for landing. The runway was selected for soil sampling based on the fact that the highest accumulation of metals is observed at the landing site [23]. A total number of 48 samples was taken from $0-25 \mathrm{~cm}$ soil depth along the runway at regular intervals on both sides of the runway in 2018. The geographical coordinates of each sampling point were recorded with a hand-held GPS device. Each sample consisted of about $1000 \mathrm{~g}$ of soil. The samples were placed in polyethylene bags and transferred to the laboratory. They were then dried at laboratory temperature and sieved through a nylon sieve $(2.0 \mathrm{~mm}$ mesh).

\subsection{Sample Processing and Analytical Methods}

The $\mathrm{pH}$ of soil samples was measured in $1 \mathrm{M} \mathrm{KCl} \mathrm{[24].} \mathrm{Total} \mathrm{organic} \mathrm{carbon}\left(\mathrm{C}_{\text {tot }}\right)$ in the soil was measured using a LECO TruSpec analyzer (MI USA). To estimate the total content of the PTEs of interest $(\mathrm{Cu}, \mathrm{Ni}, \mathrm{Pb}$, and $\mathrm{Zn})$, the decomposition was performed prior to measurements of the samples. The sample solutions were obtained by decomposing of $0.5 \mathrm{~g}$ of soil with the addition of $3 \mathrm{~mL}$ of concentrated nitric acid and $9 \mathrm{~mL}$ of concentrated hydrochloric acid in an ETHOS EASY microwave digestion oven (Milestone, Sorisole, Italy). Microwave decomposition was performed using an optimized temperature program. Step 1: gradual heating of the vessels to $200{ }^{\circ} \mathrm{C}$ for $15 \mathrm{~min}$ at $1800 \mathrm{~W}$, step 2: maintaining of the temperature $110^{\circ} \mathrm{C}$ for $15 \mathrm{~min}$ at $1800 \mathrm{~W}$, and step 3: cooling for a time period of $10 \mathrm{~min}$. Decomposition of each sample was performed twice. The individual solutions were then mixed and transferred to a volume of $50 \mathrm{~mL}$.

The contents of the selected PTEs in the soil digests were determined by means of atomic absorption spectrometry (AAS) using a high-resolution continuum source spectrometer ContrAA 800D (Analytik, Jena, Germany). The limits of detection attained according to described protocol were $30 \mu \mathrm{g} / \mathrm{kg}$ for $\mathrm{Ni}, 2 \mu \mathrm{g} / \mathrm{kg}$ for $\mathrm{Cu}, 89 \mu \mathrm{g} / \mathrm{kg}$ for $\mathrm{Pb}$, and $18 \mu \mathrm{g} / \mathrm{kg}$ for $\mathrm{Zn}$.

\subsection{Soil Toxicity Bioassay}

Soil toxicity was assessed using a commercial toxicity bioassay, the Phytotoxkit ${ }^{\mathrm{TM}}$ test [25]. The Phytotoxkit measures the decrease (or the absence) of seed germination and the growth of roots after 3 days of the exposure of the selected plant to a contaminated matrix, in comparison with the controls in the reference OECD soil. White mustard (Sinapis alba L.) was chosen for the experiment. The methodology followed the steps described by Voberrková et al. [26], Radziemska et al. [27], and Brtnický et al. [2]. The percentage root growth inhibition (RGI) was calculated with the application of the following formula:

$$
\mathrm{RGI}=\frac{\mathrm{A}-\mathrm{B}}{\mathrm{A}} \times 100
$$

where: A represents root length in the control and B represents root length in the test.

\subsection{Data Treatment}

The Geoaccumulation Index and the Nemerow Pollution Index were applied to assess soil contamination. The ecological risk was assessed using the Potential Ecological Risk Index. 


\subsubsection{Geoaccumulation Index $\left(\mathrm{I}_{\text {geo }}\right)$}

The $\mathrm{I}_{g e o}$ allows for assessing the degree of soil PTE contamination based on the knowledge of the PTE content in the background. The equation used to calculate $I_{g e o}$ is as follows [28,29]:

$$
\mathrm{I}_{\text {geo }}=\log _{2}\left(\frac{\mathrm{C}_{i}}{1.5 \mathrm{~B}_{i}}\right)
$$

where $C_{i}$ is the content of the PTE, 1.5 is constant, allowing the analysis of fluctuations of the PTE content as a result of natural processes, and $\mathrm{B}_{i}$ is the content of the corresponding PTEs in background. As a background, the background values for the Warsaw soils given by Czarnowska et al. [30] in Pichtel et al. [31] were used for $\mathrm{Cu}, \mathrm{Pb}$, and $\mathrm{Zn}$ and the local background value based on the geochemical atlas of Poland, given by Lis and Pasieczna [32], was applied as the background value for $\mathrm{Ni}(5 \mathrm{mg} / \mathrm{kg})$. The $\mathrm{I}_{\text {geo }}$ has the following classes: $\leq 0$ : uncontaminated, $0-1$ : uncontaminated to moderately contaminated, $1-2$ : moderately contaminated, $2-3$ : moderately to heavily contaminated, 3-4: heavily contaminated, $4-5$ : heavily to extremely contaminated, $\geq 5$ extremely contaminated [17].

\subsubsection{Nemerow Integrated Pollution Index $\left(\mathrm{IPI}_{N}\right)$}

The $\mathrm{IPI}_{N}$ is used to assess the degree of soil pollution. The equations employed for its calculation are as follows [20,33]:

$$
\begin{gathered}
\mathrm{PI}_{i}=\frac{\mathrm{C}_{i}}{\mathrm{~T}_{i}} \\
\mathrm{IPI}_{N}=\left[\left(\mathrm{PI}^{2}{ }_{\text {avg }}+\mathrm{PI}^{2}{ }_{\text {max }}\right) / 2\right]^{1 / 2}
\end{gathered}
$$

where $\mathrm{PI}_{i}$ is the pollution index for a single element, $\mathrm{C}_{i}$ is the content of the PTE, $\mathrm{T}_{i}$ is the target value of the PTE given by VROM [34] in this study, $\mathrm{PI}_{a v g}$ is the mean value of all $\mathrm{PI}_{i}$ of PTEs, and $\mathrm{PI}_{\max }$ is maximum $\mathrm{PI}_{i}$ value of the PTEs. $\mathrm{IPI}_{N}$ classes are as follows: $\leq 0.7$ : safe, 0.7-1: precaution, 1-2: slight pollution, 2-3: moderate pollution, $\geq 3$ : heavy pollution [17].

\subsubsection{Potential Ecological Risk Index (RI)}

This index was proposed by Håkanson [35] to assess the degree of the environmental risk. RI reflects the potential sensitivity of the biological community to PTEs. The equation applied to calculate RI is as follows [29,36]:

$$
\mathrm{RI}=\sum_{i=1}^{n} \mathrm{Er}_{i}=\sum_{i=1}^{n} \operatorname{Tr}_{i} \times \frac{\mathrm{C}_{i}}{\mathrm{~B}_{i}}
$$

where $\mathrm{Er}_{i}$ is the potential ecological risk index for a single element; $\mathrm{Tr}_{i}$ is the toxic response factor where $\mathrm{Cu}, \mathrm{Ni}, \mathrm{Pb}$, and $\mathrm{Zn}$ have values 5, 6, 5, and 1 [35,36]; $\mathrm{C}_{i}$ is the content of the PTE; and $\mathrm{B}_{i}$ is the background content of the corresponding PTE. The $\mathrm{Er}_{i}$ is categorized as [35]: $\mathrm{Er}_{i}<40$ (low potential ecological risk), $40 \leq \mathrm{Er}_{i}<80$ (moderate potential ecological risk), $80 \leq \mathrm{Er}_{i}<160$ (considerable potential ecological risk), $160 \leq \mathrm{Er}_{i}<320$ (high potential ecological risk), $\mathrm{Er}_{i} \geq 320$ (very high potential ecological risk). RI is then graded as follows [17,35]: RI $\leq 150$ (low ecological risk), $150<\mathrm{RI} \leq 300$ (moderate ecological risk), $300<\mathrm{RI} \leq 600$ (considerable ecological risk) and RI $>600$ (very high ecological risk).

\subsection{Statistical Analyses}

Data processing and all the statistical analyses were carried out with the help of a free available program R, version 3.6.3. [37], together with RStudio [38] for the writing of R scripts. The advanced graphs were created by using additional packages "ggplot2" [39] and "PerformanceAnalytics" [40].

To test the difference between the soil PTE content and the runway system, one-way analysis of variance (ANOVA) type I (sequential) sum of squares at the significance level of 0.05 [41] was used, where the soil PTE content was applied as a continuous response variable and the runway system 
as a categorical explanatory variable. To measure the effect size, partial eta-squared (np2) from the "BaylorEdPsych" package was used [42]. "Treatment contrast" was applied for calculating factor level means with a $95 \%$ confidence interval [43].

The simple linear regression analysis was performed for modelling the relation between phytotoxicity and the RI, while the multiple linear regression analysis was applied in order to characterize the relation between phytotoxicity and $\mathrm{Er}_{i}$ [44], where phytotoxicity was used as a continuous response variable in both cases. Measuring of the strength of the linear relation between the selected variables was carried out with the help of Pearson's correlation coefficient and the results were presented by using the correlation matrix. During the regression analysis, the best-fitting curve was obtained by the method of ordinary last squares (OLS). The coefficient of determination $\left(R^{2}\right)$ was applied for the measurement of how close the data fit the regression line. The adjusted R-squared $\left(\right.$ adj- $R^{2}$ ) was used to measure the effect size of these factors, which have a real impact on the response variable. The relative importance of all the individual regressors' contributions to the multiple linear model was assessed by using "last relation importance metric". In the graphs, the size effect of each explanatory variable was represented in percentages. For this purpose, the "relaimpo" additional package [45] was employed. Finally, locally estimated scatterplot smoothing (LOESS) was performed for the fitting of the regression curve with $95 \%$ interval confidence $(\mathrm{CI})$ around the regression line. The smoothing method was chosen based on the size of the largest group and the smoothing parameter $(\alpha)$ was 0.8 , which means the loess curve incorporated $80 \%$ of the total data points [46].

After conducting the analysis, all the statistical models were checked at the significance level 0.05 with the help of different statistical tests and diagnostic plots. For testing the normality of the data, the Kolmogorov-Smirnov test and the Shapiro-Wilk normality test from the "nortest" package [47] were used, whereas for testing homoscedasticity, Bartlett's and Levene's tests were applied from the "car" package [48]. The D'Agostino's K-squared test was used for testing skewness, while the Anscombe-Glynn test was employed for testing the kurtosis from the "moments" package [49]. To detect outliers in the data, the Grubb's test from the "outliers" package [50] and Cook's distance test were used. The Durbin-Watson test from "lmtest" package [51] was used for measuring of autocorrelation in the residuals from the regression analysis. For testing the multicollinearity among independent variables (also the strength of this correlation), the variance inflation factor (VIF) from "faraway" package [52] and the Farrar-Glauber test from the "mctest" package were applied [53-55].

\section{Results and Discussion}

The rapid development of the air transport sector has led to negative changes in the natural environment [6]. The basic fuel applied in air traffic is jet fuel-kerosene, which is a product of the distillation of crude oil. Jet fuel contains trace amounts of PTEs, though the greatest threat to the environment connected with air transport is the emission of $\mathrm{Pb}$ [56].

The resulting contents of the monitored PTEs indicate (Table 1) that the pollution of the airport soils in the vicinity of the runway by these elements is low. $\mathrm{Cu}$ and $\mathrm{Ni}$, in particular, showed relatively balanced values at $14.02 \mathrm{mg} / \mathrm{kg}(95 \% \mathrm{CI}[11.36,16.69])$ and $8.83 \mathrm{mg} / \mathrm{kg}(95 \% \mathrm{CI}[7.44,10.21])$, respectively. The situation was different in the case of $\mathrm{Pb}$ and $\mathrm{Zn}$, which have already achieved more significant deviations from the background values and an overall larger variance of the values, at $64.18 \mathrm{mg} / \mathrm{kg}$ (95\% CI [44.76,83.61]) and $151.73 \mathrm{mg} / \mathrm{kg}(95 \%$ CI [82,43,221.04]). The average content of none of the elements exceeded the permissible content in the urban soils of Poland [57]. Exceedance was detected for $\mathrm{Pb}$ only once, and in the case of $\mathrm{Zn}$ twice.

When confronted with the background values through the $\mathrm{I}_{g e o}$ assessment (Table 1), Zn contamination was confirmed, whereas $\mathrm{Cu}, \mathrm{Ni}$, and $\mathrm{Pb}$ fell into the category of uncontaminated to moderately contaminated with the $\mathrm{I}_{\text {geo }}$ values of 0.23 (95\% CI [0,0.49]), 0.08 (95\% CI [0,0.27]), and 0.79 (95\% CI [0.55,1.03]); Zn had already fallen into the category moderately contaminated with a value of 1.16 (95\% CI [0.69,1.62]). The overall low level of pollution was also confirmed by the total $\operatorname{IPI}_{N}$, which classifies the monitored soils in the vicinity of the runway into the category of slight pollution at the value of $1.04(95 \% \mathrm{CI}$ 
$[0.67,1.42])$. Based on these results, it can be stated that airport traffic in this case causes merely slight soil pollution, which is mainly due to $\mathrm{Zn}$ and partially $\mathrm{Pb}$. The results may, however, be slightly affected (underestimated) by runway reconstruction in 2010, though it is difficult to assess the impact of the reconstruction on the soil quality.

Table 1. Potentially toxic elements contents $(C$, in $\mathrm{mg} / \mathrm{kg})$ and pollution indices.

\begin{tabular}{|c|c|c|c|c|c|c|c|c|c|}
\hline & \multicolumn{2}{|c|}{$\mathrm{Cu}$} & \multicolumn{2}{|c|}{$\mathbf{N i}$} & \multicolumn{2}{|c|}{$\mathrm{Pb}$} & \multicolumn{2}{|c|}{ Zn } & \multirow{2}{*}{$\mathbf{I P I}_{N}$} \\
\hline & $\mathrm{C}$ & $\mathbf{I}_{\text {geo }}$ & $\mathrm{C}$ & $\mathbf{I}_{\text {geo }}$ & $\mathrm{C}$ & $\mathbf{I}_{\text {geo }}$ & C & $\mathbf{I}_{\text {geo }}$ & \\
\hline Mean & 14.0 & 0.23 & 8.83 & 0.08 & 64.2 & 0.79 & 152 & 1.16 & 1.04 \\
\hline SEM $^{\mathrm{a}}$ & 1.33 & 0.13 & 0.69 & 0.09 & 9.65 & 0.12 & 34.5 & 0.23 & 0.19 \\
\hline S.D. ${ }^{b}$ & 9.19 & 0.88 & 4.77 & 0.65 & 66.9 & 0.82 & 239 & 1.58 & 1.29 \\
\hline Minimum & 2.58 & -1.89 & 3.67 & -1.03 & 22.3 & -0.43 & 3.96 & -3.24 & 0.24 \\
\hline Lower Quartile (25\%) & 7.47 & -0.36 & 5.83 & -0.36 & 36.3 & 0.28 & 48.3 & 0.37 & 0.42 \\
\hline Median (50\%) & 10.3 & 0.05 & 8.35 & 0.15 & 45.6 & 0.60 & 87.1 & 1.22 & 0.62 \\
\hline Upper Quartile (75\%) & 18.3 & 0.90 & 10.9 & 0.53 & 75.6 & 1.33 & 186 & 2.31 & 1.10 \\
\hline Maximum & 41.3 & 2.10 & 32.6 & 2.12 & 473 & 3.98 & 1581 & 5.40 & 8.27 \\
\hline Background & $6.4^{c}$ & & $5^{d}$ & & $20^{c}$ & & $25^{\mathrm{a}}$ & & \\
\hline Limit PL e & 200 & & 150 & & 200 & & 500 & & \\
\hline
\end{tabular}

a Standard error of the mean; ${ }^{\mathrm{b}}$ standard deviation; ${ }^{\mathrm{c}}$ background values for Warsaw soils [30,31]; ${ }^{\mathrm{d}}$ background value based on the geochemical atlas of Poland [32]; e permissible content in urban soils of Poland [57].

Rao et al. [21], in their study, related air traffic to environmental contamination by $\mathrm{Cd}$ and $\mathrm{Pb}$. Other elements $(\mathrm{Cu}, \mathrm{Cr}, \mathrm{Ni}$, and $\mathrm{Zn})$ were then associated with natural sources in that study. In the similar research on the effect of aircraft traffic emission on soil pollution, Ray et al. [23] designated air transport as a possible emitter of $\mathrm{Cu}, \mathrm{Pb}, \mathrm{Zn}, \mathrm{Cr}$, and $\mathrm{Ni}$ causing soil contamination, especially by $\mathrm{Cd}$ and $\mathrm{Pb}$. Likewise, Massas et al. [16] linked air traffic with possible emissions of $\mathrm{Cu}, \mathrm{Pb}, \mathrm{Zn}$, and, to a limited extent, Ni. Brtnický et al. [17], in a study dealing with soil contamination in the vicinity of the airport, related air traffic mainly to $\mathrm{Zn}$ contamination, but also mentioned contamination caused by Co and $\mathrm{Cr}$, which were not, however, monitored in this study. Further research on this issue is needed for a more precise definition of air traffic-emitted elements causing soil contamination or pollution because, in most of the mentioned studies, the results may be misrepresented by car traffic. This can be external, but also directly connected to the operation of airports. Airport ground service equipment, which includes, for instance, refilling trucks, passenger buses, baggage carriers, container loader, de/anti-icing vehicles, and tugs, can constitute another significant source of pollution [7]. Despite this, aircraft movements are considered the main sources of particles in the airfield [58].

The fuel combustion and combustion of oil are the primary emission sources for the aircraft operation [59]. Approximately $25 \%$ of the exhaust emissions from the aircraft operation are produced during the take-off and landing cycle [60], so this cycle can be a major source of pollution at airports. Turgut et al. [59] stated that aviation aircraft emissions associated with combustion can be significantly enriched, in particular with $\mathrm{Pb}$, but also with $\mathrm{Cd}, \mathrm{Cu}, \mathrm{Ni}$, or $\mathrm{Zn}$. Ray et al. [22] also stated, that since $\mathrm{Cu}$, $\mathrm{Pb}$, and $\mathrm{Zn}$ are used as additives to aviation fuels, they can be released in these emissions. Rao et al. [23] reported their importance to soil contamination at airports. Less explored is the difference between take-off and landing in these emissions.

Although the studied runway is mainly used for landing [61], there is a possibility for both take-off and landing. Considering the preferential runway system [62], it is possible to track differences between them in the soil PTE content. The difference can be observed especially in the case of $\mathrm{Pb}$ (Figure 1). In the case of the arrival runway, the average $\mathrm{Pb}$ content value was $40.8 \mathrm{mg} / \mathrm{kg}(95 \% \mathrm{CI}$ $[7.8,73.7])$, while in the case of the departure runway, the value was $75.9 \mathrm{mg} / \mathrm{kg}(95 \% \mathrm{CI}[52.6,99.2])$. A higher average value was also found in the case of $\mathrm{Cu}$. However, in all the cases, this difference was not statistically significant $(p>0.05)$, probably due to the lack of samples (small dataset) and possible insufficient separation of the operations. Given that, during take-off, high engine thrust, and large fuel 
consumption are required, there is also the higher production of emissions than in other operations [63]. In this case, this was observed for $\mathrm{Pb}$ and $\mathrm{Cu}$, though it was not statistically confirmed.

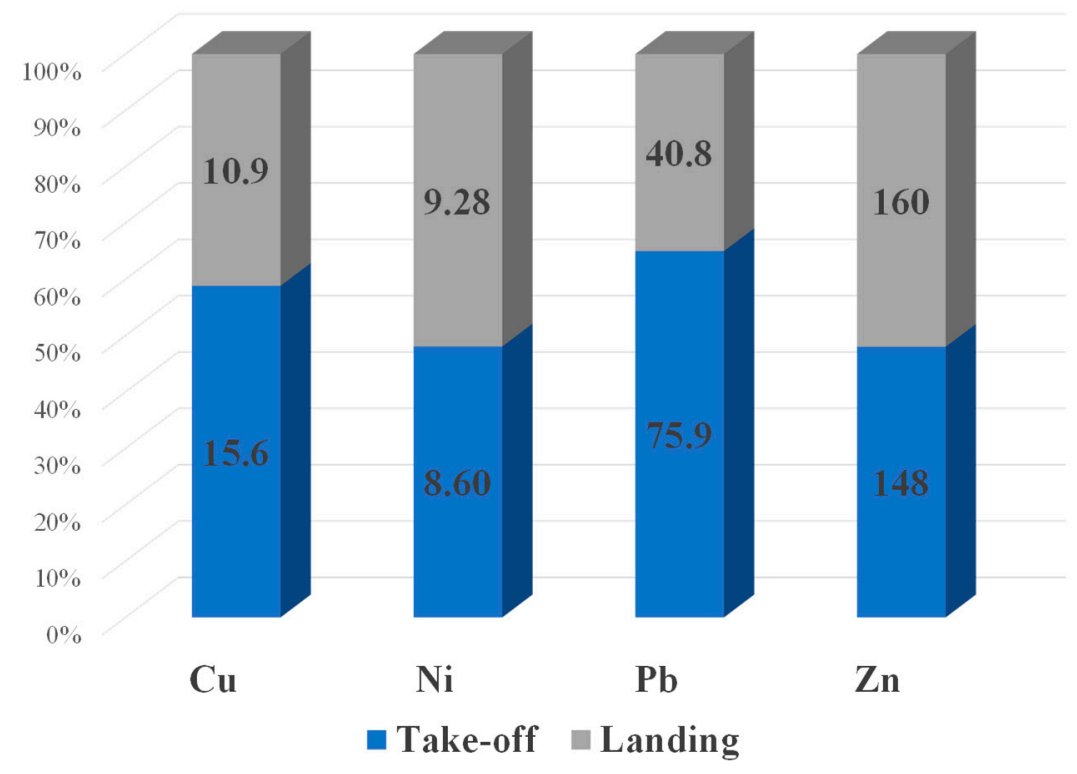

Figure 1. The comparison of the landing and take-off parts of the runway.

Particles released during aircraft movement enter the environment immediately close to the runways and, due to atmospheric deposition, can settle in the soils of airports [64]. The high level of emission of contaminants may pertain not only to higher zones of the troposphere, but also the airports. Components of potentially harmful emission also include particulates from the wear of tires, runway surfaces, and brakes of planes during taxiing. The composition of the formed particulates includes polymers and PTEs such as $\mathrm{Zn}, \mathrm{Mo}$, and $\mathrm{Cu}$ [6]. The observed increased amount of $\mathrm{Zn}$ is frequently associated with tire wear [65-67]. The extreme conditions to which tires are exposed on the runway may result in the contamination of airport soils by Zn. In addition to Zn, other PTEs may be released from tire wear [10], for example $\mathrm{Cd}, \mathrm{Cr}, \mathrm{Cu}, \mathrm{Ni}$, or $\mathrm{Pb}$ [68]. Janić [15] related soil pollution at airports to leakage from storage tanks. Batteries and accumulators containing $\mathrm{Cd}$ and $\mathrm{Ni}$ can also represent a problem; $\mathrm{Cr}$ may be derived from the abrasion of primers applied to aircraft surfaces to prevent corrosion [23]. Brake or asphalt wear can also be a source of PTEs [15]; in particular, $\mathrm{Cu}$ is associated with brake wear and its increasing emissions are related to an increasing number of landings [65]. Owing to the constant growth of traffic at this airport [22], a faster increase in contamination can be expected in the future.

However, on account of the intense airflow at airports, contamination of airport oils may be slightly misinterpreted. Turbulence created by the aircraft movements can end in resuspension of contaminated particles [7]. Released PTE particles can be quickly and easily transported over longer distances by air, and therefore the soil itself near the runways does not have to evince such signs of pollution that would correspond to the pollutants actually emitted. What is more, Bennett et al. [66] stated that PM emissions from tires and brakes are dependent on many factors, including, for instance, weather conditions. Apart from air transport, significant transport of pollutants can also occur via water. Calijuri et al. [69] reported that emitted pollutants can be carried by rainwater into the airport's drainage system and subsequently transported to more remote areas. Even though the soil is reported to be a good sink for monitoring of traffic pollution [21,33], the environment needs to be monitored comprehensively in the case of airports, and air or water pollution should be addressed on a larger scale.

Figure 2 shows the correlation matrix of the soil PTE contents and other soil properties. The strongest positive correlation was identified between $C$ and $C u$ (Pearson's $r(48)=0.43, p=0.002$ ). No correlation was demonstrated between $\mathrm{C}$ and Ni (Pearson's r $(48)=-0.09, p=0.52), \mathrm{C}$ and $\mathrm{Pb}$ 
(Pearson's r $\mathrm{r}(48)=0.01, p=0.92$ ), or between C and Zn (Pearson's r $(48)=-0.01, p=0.93$ ). In the case of $\mathrm{pH}$, the strongest positive correlation was noted between $\mathrm{pH}$ and $\mathrm{Cu}$ (Pearson's $\mathrm{r}(48)=0.40, p=0.005$ ) and between $\mathrm{pH}$ and $\mathrm{Ni}$ (Pearson's $\mathrm{r}(48)=0.32, p=0.02$ ). No correlation was ascertained between $\mathrm{pH}$ and $\mathrm{Pb}$ (Pearson's r $(48)=-0.04, p=0.78$ ) or between $\mathrm{pH}$ and $\mathrm{Zn}$ (Pearson's $\mathrm{r}(48)=-0.03, p=0.87$ ). Although organic matter (in this study $\mathrm{C}_{t o t}$ ) and $\mathrm{pH}$ are important soil properties affecting the content of PTEs in the soil and their mobility [16,18], their effect is not so significant in this case, owing to the balanced values at the $\mathrm{pH}$ range, which are usually close to neutral (5.5-7.6; average value 6.8) and the $\mathrm{C}_{\text {tot }}$ range $0.4-3.0 \%$ (1.3\% on average). The obtained soil $\mathrm{pH}$ values detected along the runway revealed alkaline conditions, which may indicate low metal mobility in the analyzed soils. The $\mathrm{pH}$ values were similar to those obtained by Massas et al. [13], who tested this parameter in the soils in the close proximity to the Athens International Airport in Greece.

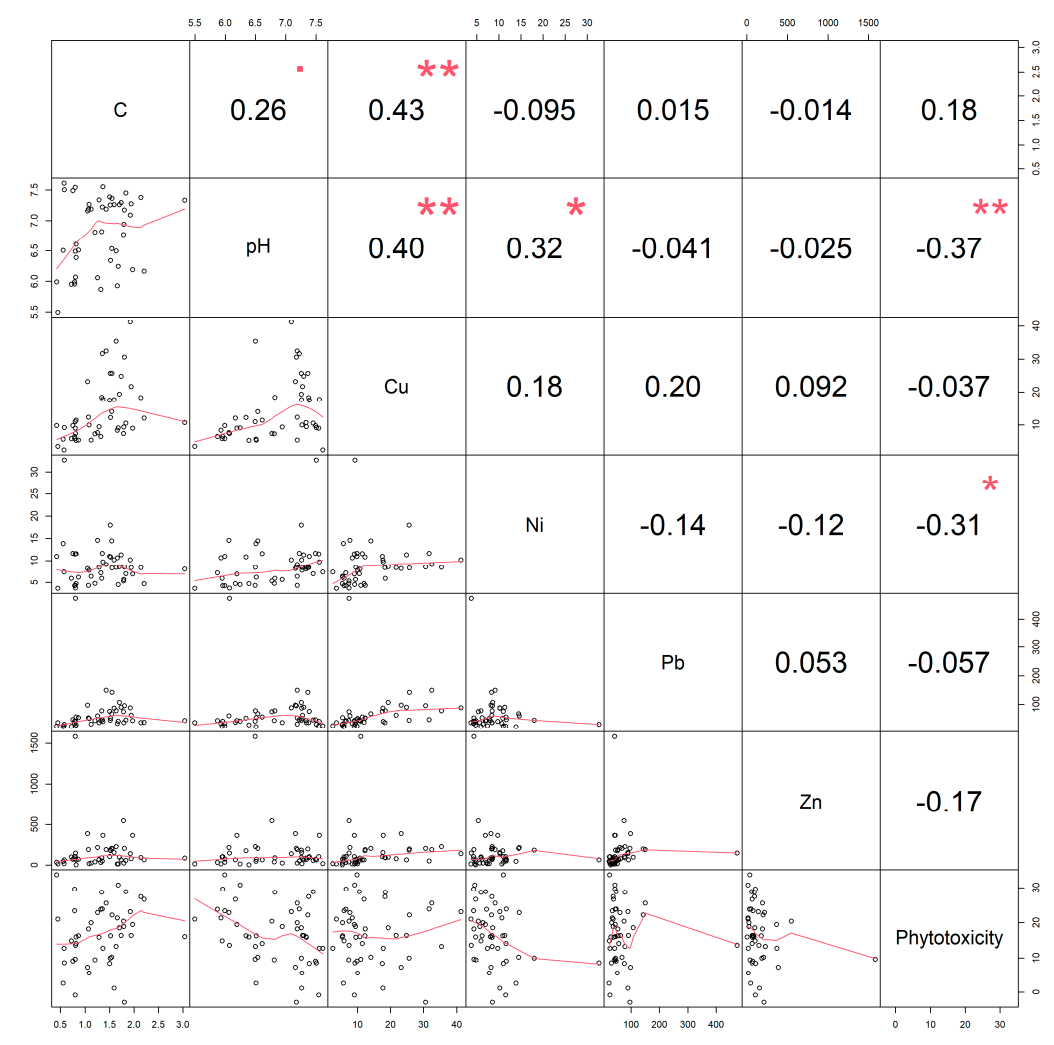

- statistically significant difference at $10 \%$ significance level; ${ }^{*}$ statistically significant difference at $5 \%$ significance level; ${ }^{* *}$ statistically significant difference at $1 \%$ significance level.

Figure 2. Correlation matrix of the soil PTE contents and the selected soil properties.

$\mathrm{The}_{i}$ vegetation risk assessment demonstrated that all the elements ranked among the low potential ecological risk category with the average values for $\mathrm{Cu}: 10.96$ (95\% CI [8.87,13.04]), Ni: 10.59 (95\% CI [8.93,12.26]), Pb: 16.05 (95\% CI [11.19,20.90]), and Zn: 6.07 (95\% CI [3.30,8.84]). The overall RI assessment manifested the low ecological risk at the value of 43.67 (95\% CI [37.12,50.21]). On the contrary, evaluation of the soils by means of the phytotoxicity test indicated an average inhibition of $16.7 \%$ (95\% CI [14.25,19.17]), with a maximum growth inhibition reaching the value of $33.7 \%$.

Contamination of the soil environment with PTEs has a negative influence on human health, as well as the environment, due to their ecotoxicity. On the grounds of the results of the linear multiple regression, it can be concluded that there is no statistically significant relation between phytotoxicity and $\operatorname{Er}_{i}(\mathrm{~F} 4,43=1.94 ; p=0.12)$, with the $\mathrm{R}^{2}$ of 0.15 , and therefore this model cannot be used to predict the alteration in phytotoxicity with dependence of $\mathrm{Er}_{i}$. Nevertheless, within this model, the impact of $\mathrm{Er}_{i} \mathrm{Ni}$ was statistically significant $(p=0.02)$. Predicted phytotoxicity was equal to $23.54+0.09^{*} \mathrm{Er}_{i}$. 
$\mathrm{Cu}-0.54^{*} \mathrm{Er}_{i} \cdot \mathrm{Ni}-0.06^{*} \mathrm{Er}_{i} \cdot \mathrm{Pb}-0.19^{*} \mathrm{Er}_{i} . \mathrm{Zn}$, where phytotoxicity is expressed by percentage. The relative contributions of predictors in the case of phytotoxicity were (in the descending order): $66 \%$ ( $\mathrm{Er}_{i}$ of $\mathrm{Ni}$ ), $25 \%\left(\mathrm{Er}_{i}\right.$ of $\left.\mathrm{Zn}\right), 6 \%\left(\mathrm{Er}_{i}\right.$ of $\left.\mathrm{Pb}\right)$, and 3\% ( $\mathrm{Er}_{i}$ of $\mathrm{Cu}$ ) (Figure 3).

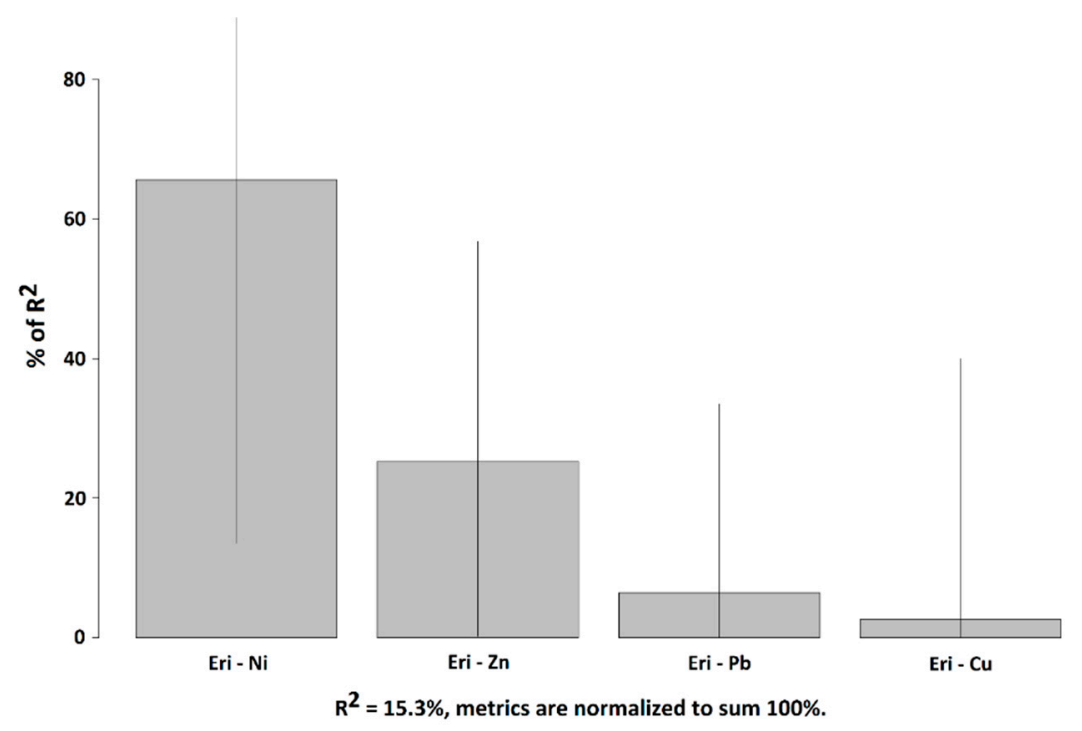

Figure 3. Relative importance for phytotoxicity (by the method last and with $95 \%$ bootstrap confidence intervals).

The relationship between $\mathrm{Ni}$ and phytotoxicity was also confirmed by a low negative correlation between Ni and phytotoxicity (Pearson's $\mathrm{r}(48)=-0.31, p=0.03$ ) (Figure 2 ). The importance of Ni in this case may be associated with its roles in plants. Nickel is a crucial micronutrient and an essential component of some enzymes (e.g., ureases) for plants, which is important for the normal plant growth and development $[19,70]$. Its content in the monitored soils was relatively low (Table 1), and therefore its increasing content can act as a growth stimulant, which was monitored within the phytotoxicity test. This hypothesis is also supported by Sreekanth et al. [71], who reported that Ni enhances seed germination and seedling vigor.

Based on the results of the linear regression model between phytotoxicity and RI, it can be concluded that there is no relation between the two, and it is therefore not possible to predict phytotoxicity based on RI $(\mathrm{F} 1,46=2.04 ; p=0.16)$ with the $\mathrm{R}^{2}$ of 0.04 in this case. The predicted phytotoxicity was equal to $20.09-0.07^{*} \mathrm{RI}$, where phytotoxicity is expressed by percentage. The absence of a relation between RI and phytotoxicity is evident from Figure 4, as well. On the basis of this fact, it can be stated that factors other than the observed PTEs, which negatively affect the plant growth, bring about toxicity in this case. Owing to the moderate negative correlation between phytotoxicity and $\mathrm{pH}$ (Pearson's r $(48)=-0.37, p=0.01$ ) (Figure 2), it can be assumed that the decrease in $\mathrm{pH}$ causes the increase in the mobility of these substances and their higher availability to plants, which is common for PTEs [18]. Therefore, other PTEs, such as Cd, can also be toxicants.

Mander et al. [68] related air transport to the increased Cd content in soils and plants in the vicinity of runways. Similarly, Ray et al. [23] and Rao et al. [21] linked airport soils to contamination by $\mathrm{Cd}$. Cadmium is highly phytotoxic to plants $[18,19]$. This hypothesis regarding the risk of Cd to plant life in airport soils is also supported by Rao et al. [21], who identified its high potential ecological risk indicating potential harm to plants in their study monitoring the contamination of airport soils.

The RI assessment by means of merely four elements was insufficient in this case and points to the need to address the impacts on flora comprehensively through phytotoxicity tests in initial studies.

Even though airports do not have to pose a major threat to adjacent vegetation and the soil environment from the point of view of soil PTE pollution, noise [14,72,73], and air pollution $[15,60]$, having the worst local impact in connection with air transport services remains a major risk [4]. 
Noise pollution can affect local people through a number of possible impacts, including negative health effects, namely stress-related psychosocial symptoms; cardiovascular diseases; and sleep disturbances $[72,73]$. In the future, it is therefore necessary to pay particular attention to those issues, which may be especially problematic in urban areas. From the standpoint of soil pollution, further research is needed to monitor the distribution of PTEs in the wider environment in connection with air pollution.

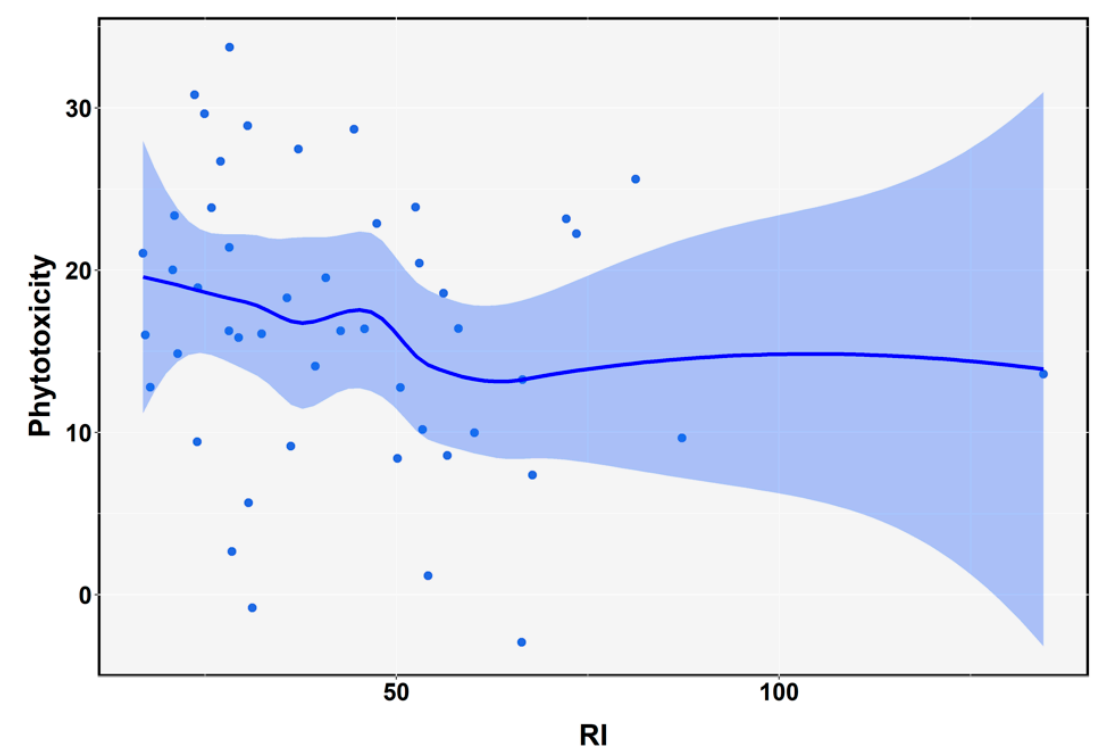

Figure 4. Relation between the Potential Ecological Risk Index (RI) and phytotoxicity.

\section{Conclusions}

The outcomes of the monitored PTEs evinced low soil pollution in the vicinity of the airport runway. The $\mathrm{IPI}_{N}$ assessment categorized the monitored soils as slightly polluted, whereas the $\mathrm{I}_{\text {geo }}$ assessment indicated moderate contamination by $\mathrm{Zn}$ and none to moderate contamination by $\mathrm{Cu}, \mathrm{Ni}$, and $\mathrm{Pb}$. Nevertheless, due to the constant growth of traffic at the monitored airport, the increase in contamination can be expected in the future. The sources of pollution are probably emissions from aircraft tires and brakes. A significant difference between the take-off and landing parts runway in the soil PTE content was not statistically confirmed, probably due to the lack of samples or possible insufficient separation of the operations, because the runway is mainly used for landing.

The results of other studies have indicated that the range of elements and the extent of contamination can be highly variable at different airports and frequently affected by car traffic. Therefore, further research on this issue is needed for a more precise definition of the elements emitted by air traffic at airports. Although the soil is a good sink for traffic pollution monitoring, the environment in the case of airports needs to be monitored comprehensively and air as well as water pollution also needs to be addressed on a larger scale. Vegetation risk assessment by $\mathrm{Er}_{i}$ and RI showed the low ecological risk, while soil assessment by means of the phytotoxicity test demonstrated an average slight inhibition of $16.7 \%$, and thus the low toxic impact of airport traffic on airport vegetation. Owing to the result of the linear regression model between phytotoxicity and RI, it can be concluded that there is no relation between them. It is therefore not possible to predict phytotoxicity based on RI. On the grounds of this fact, it can be stated that other factors cause toxic effects in this case. A possible toxic element may be $\mathrm{Cd}$, which is commonly associated with air transport.

Author Contributions: Conceptualization, M.B. and V.P.; methodology, M.B. and V.P.; software, T.B.; validation, M.B., V.P., M.V.G. and M.R.; formal analysis, M.V.G. and L.B.; investigation, M.B., V.P. and M.R.; resources, M.B. and M.R.; data curation, T.B.; writing-original draft preparation, M.B. and V.P.; writing-review and editing, M.B., V.P., M.V.G., L.B. and M.R.; visualization, M.B., V.P. and M.R.; supervision, M.V.G., A.B. and M.R.; project 
administration, V.P.; funding acquisition, A.B. All authors have read and agreed to the published version of the manuscript.

Funding: This research received no external funding.

Acknowledgments: The work was supported by the project of Ministry of Education, Youth and Sports of the Czech Republic FCH-S-20-6446.

Conflicts of Interest: The authors declare no conflict of interest.

\section{References}

1. Brtnický, M.; Pecina, V.; Hladký, J.; Radziemska, M.; Koudelková, Z.; Klimánek, M.; Richtera, L.; Adamcová, D.; Elbl, J.; Galiová, M.V.; et al. Assessment of phytotoxicity, environmental and health risks of historical urban park soils. Chemosphere 2019, 220, 678-686. [CrossRef] [PubMed]

2. Pollock, S.Z.; Clair, C.C.S. Railway-associated attractants as potential contaminants for wildlife. Environ. Manag. 2020,1-14. [CrossRef] [PubMed]

3. Schäfer, A.W.; Waitz, I.A. Air transportation and the environment. Transp. Pol. 2014, 34, 1-4. [CrossRef]

4. Trojanek, R.; Huderek-Glapska, S. Measuring the noise cost of aviation-The association between the Limited Use Area around Warsaw Chopin Airport and property values. J. Air Transp. Manag. 2018, 67, 103-114. [CrossRef]

5. Addepalli, S.; Pagalday, G.; Salonitis, K.; Roy, R. Socio-economic and demographic factors that contribute to the growth of the civil aviation industry. Proc. Manufactur. 2018, 19, 2-9. [CrossRef]

6. Kamiński, M.; Pospolita, W.; Cholewiński, M.; Łagocka, A. Emisja zanieczyszczeń z sektora transportu lotniczego i jej wpływ na zdrowie człowieka. Kosmos 2016, 65, 487-493. (In Polish)

7. Masiol, M.; Harrison, R.M. Aircraft engine exhaust emissions and other airport-related contributions to ambient air pollution: A review. Atmos. Environ. 2014, 95, 409-455. [CrossRef]

8. IATA International. Air Transp. Assoc. Ann. Rev. 2019. Available online: https://www.iata.org/contentassets/ c81222d96c9a4e0bb4ff6ced0126f0bb/iata-annual-review-2019.pdf (accessed on 17 February 2020).

9. Donzelli, M. The effect of low-cost air transportation on the local economy: Evidence from Southern Italy. J. Air Transp. Manag. 2010, 16, 121-126. [CrossRef]

10. Jones, S.; Richardson, N.; Bennett, M.; Hoon, S.R. The application of magnetic measurements for the characterization of atmospheric particulate pollution within the airport environment. Sci. Total Environ. 2015, 502, 385-390. [CrossRef]

11. Hudda, N.; Fruin, S.A. International airport impacts to air quality: Size and related properties of large increases in ultrafine particle number concentrations. Environ. Sci. Technol. 2016, 50, 3362-3370. [CrossRef]

12. Rahim, M.F.; Pal, D.; Ariya, P.A. Physicochemical studies of aerosols at Montreal Trudeau Airport: The importance of airborne nanoparticles containing metal contaminants. Enviton. Poll. 2019, 246, 734-744. [CrossRef] [PubMed]

13. Massas, I.; Gasparatos, D.; Ioannou, D.; Kalivas, D. Signs for secondary build up of heavy metals in soils at the periphery of Athens International Airport, Greece. Environ. Sci. Poll. Res. 2018, 25, 658-671. [CrossRef] [PubMed]

14. Ozkurt, N.; Sari, D.; Akdag, A.; Kutukoglu, M.; Gurarslan, A. Modeling of noise pollution and estimated human exposure around İstanbul Atatürk Airport in Turkey. Sci. Total Environ. 2014, 482, 486-492. [CrossRef] [PubMed]

15. Janić, M. Aviation and externalities: The accomplishments and problems. Transport. Res. D Trans. Environ. 1999, 4, 159-180. [CrossRef]

16. Massas, I.; Ioannou, D.; Kalivas, D.; Gasparatos, D. Distribution of heavy metals concentrations in soils around the international Athens airport (Greece). An assessment on preliminary data. Bull. Geol. Soc. Greece 2016, 50, 2231-2240. [CrossRef]

17. Brtnický, M.; Pecina, V.; Galiová, M.V.; Prokeš, L.; Zvěřina, O.; Juřička, D.; Klimánek, M.; Kynický, J. The impact of tourism on extremely visited volcanic island: Link between environmental pollution and transportation modes. Chemosphere 2020, 126118. [CrossRef]

18. Xie, Y.; Fan, J.; Zhu, W.; Amombo, E.; Lou, Y.; Chen, L.; Fu, J. Effect of heavy metals pollution on soil microbial diversity and bermudagrass genetic variation. Front. Plant Sci. 2016, 7, 755. [CrossRef] 
19. Amari, T.; Ghnaya, T.; Abdelly, C. Nickel, cadmium and lead phytotoxicity and potential of halophytic plants in heavy metal extraction. S. Afr. J. Bot. 2017, 111, 99-110. [CrossRef]

20. Huang, Y.; Chen, Q.; Deng, M.; Japenga, J.; Li, T.; Yang, X.; He, Z. Heavy metal pollution and health risk assessment of agricultural soils in a typical peri-urban area in southeast China. J. Environ. Manag. 2018, 207, 159-168. [CrossRef]

21. Rao, P.; Zhu, A.; Yao, W.; Zhang, W.; Men, Y.; Ding, G. Sources and risk assessment of metal contamination in soils at the international airport of Shanghai, China. Tox. Environ. Chem. 2015, 96, 1153-1161. [CrossRef]

22. Warsaw Chopin Airport, Historia Lotniska Chopina. Available online: https://www.lotnisko-chopina.pl/pl/ historia.html (accessed on 13 February 2020).

23. Ray, S.; Khillare, P.S.; Kim, K.H. The effect of aircraft traffic emissions on the soil surface contamination analysis around the international airport in Delhi, India. Asian J. Atmos. Environ. 2012, 6, 118-126. [CrossRef]

24. ISO 10390 Soil Quality_Determination of pH, second ed. 2005. SO/TC 190/SC 3. Chemical Methods and Soil Characteristics. 2005. Available online: https://www.iso.org/standard/40879.html (accessed on 21 March 2020).

25. Phytotoxkit. Seed Germination and Early Growth Microbiotest with Higher Plants. Standard Operation Procedure; MicroBioTests Inc.: Nazareth, Belgium, 2004; pp. 1-24.

26. Voběrková, S.; Vaverková, M.D.; Burešová, A.; Adamcová, D.; Vršanská, M.; Kynický, J.; Brtnický, M.; Adam, V. Effect of inoculation with white-rot fungi and fungal consortium on the composting efficiency of municipal solid waste. Waste Manag. 2017, 61, 157-164. [CrossRef]

27. Radziemska, M.; Vaverková, M.D.; Adamcová, D.; Brtnický, M.; Mazur, Z. Valorization of fish waste compost as a fertilizer for agricultural use. Waste. Biom. Valor. 2019, 10, 2537-2545. [CrossRef]

28. Müller, G. Index of geoaccumulation in sediments of the Rhine River. Geojournal 1969, 2, 108-118.

29. Kowalska, J.B.; Mazurek, R.; Gąsiorek, M.; Zaleski, T. Pollution indices as useful tools for the comprehensive evaluation of the degree of soil contamination-A review. Environ. Geochem.Health 2018, 40, 2395-2420. [CrossRef]

30. Czarnowska, K.; Gworek, B.; Kozanecka, T.; Latuszek, B.; Szafranska, E. Heavy metals content in soils as indicator of urbanization. Pol. Ecol. Stud. 1983, 9, 63-79.

31. Pichtel, J.; Sawyerr, H.T.; Czarnowska, K. Spatial and temporal distribution of metals in soils in Warsaw, Poland. Environ. Poll. 1997, 98, 169-174. [CrossRef]

32. Lis, J.; Pasieczna, A. Geochemical Atlas of Poland (Atlas Geochemiczny Polski); The Polish Geological Institute: Warsaw, Poland, 1995. (In Polish)

33. Gasiorek, M.; Kowalska, J.; Mazurek, R.; Pająk, M. Comprehensive assessment of heavy metal pollution in topsoil of historical urban park on an example of the Planty Park in Krakow (Poland). Chemosphere 2017, 179, 148-158. [CrossRef]

34. VROM. Circular on Target Values and Intervention Values for SOIL Remediation; Dutch Ministry of Housing Spatial Planning and Environment (VROM): The Hague, The Netherlands, 2013.

35. Håkanson, L. An ecological risk index for aquatic pollution control. A sedimentological approach. Water Res. 1980, 14, 975-1001. [CrossRef]

36. Qing, X.; Yutong, Z.; Shenggao, L. Assessment of heavy metal pollution and human health risk in urban soils of steel industrial city (Anshan), Liaoning, Northeast China. Ecotox. Environ. Safe. 2015, 120, 377-385. [CrossRef]

37. R Core Team. R: A Language and Environment for Statistical Computing; R Foundation for Statistical Computing: Vienna, Austria, 2020; Available online: http://www.R-project.org/ (accessed on 26 March 2020).

38. RStudio Team RStudio. Integrated Development for R; RStudio, Inc.: Boston, MA, USA, 2015; Available online: http://www.rstudio.com/ (accessed on 26 March 2020).

39. Wickham, H. ggplot2: Elegant Graphics for Data Analysis; Springer: New York, NY, USA, 2016.

40. Peterson, B.G.; Carl, P. PerformanceAnalytics: Econometric Tools for Performance and Risk Analysis. R Package Version 2.0.4. Available online: https:/CRAN.R-project.org/package=PerformanceAnalytics (accessed on 26 March 2020).

41. Zar, J.H. Biostatistical Analysis, 2nd ed.; Prentice-Hall: London, UK, 1984.

42. Beaujean, A.A. BaylorEdPsych: R Package for Baylor University Educational Psychology Quantitative Courses. R Package Version 0.5. Available online: https:/CRAN.R-project.org/package=BaylorEdPsych (accessed on 26 March 2020).

43. Faraway, J.J. Linear Models with R; Chapman \& Hall/CRC: Boca Raton, FL, USA, 2005; 229p, ISBN 1-58488-425-8. 
44. Pekár, S.; Brabec, M. Modern Analysis of Biological Data. In Generalized Linear Models in R; Masaryk University Press: Brno, Czech Republic, 2016; p. 226. ISBN 978-80-210-8019-5.

45. Grömping, U. Relative Importance for Linear Regression in R. The Package relaimpo. J. Stat. Softw. 2006, 17, 1-27. [CrossRef]

46. Jacoby, W.G. LOESS: A nonparametric, graphical tool for depicting relationships between variables. Electoral Stud. 2000, 19, 577-613. [CrossRef]

47. Gross, J.; Ligges, U. Nortest: Tests for Normality. R package Version 1.0-4. Available online: http://CRAN.Rproject.org/package=nortest (accessed on 26 March 2020).

48. Fox, J.; Weisberg, S. An R Companion to Applied Regression, 3rd ed.; Sage Publications: Thousand Oaks, CA, USA, 2019; Available online: https://socialsciences.mcmaster.ca/jfox/Books/Companion/ (accessed on 26 March 2020).

49. Komsta, L.; Novomestky, F. Moments: Moments, Cumulants, Skewness, Kurtosis and Related Tests. R package Version 0.14. Available online: https://CRAN.R-project.org/package=moments (accessed on 26 March 2020).

50. Komsta, L. Outliers: Tests for Outliers. R Package Version 0.14. Available online: https://CRAN.R-project. org/package=outliers (accessed on 26 March 2020).

51. Zeileis, A.; Hothorn, T. Diagnostic Checking in Regression Relationships. R News 2002, 2, 7-10. Available online: https://CRAN.R-project.org/doc/Rnew/ (accessed on 26 March 2020).

52. Faraway, J. faraway: Functions and Datasets for Books by Julian Faraway. R Package Version 1.0.7. Available online: https:/CRAN.R-project.org/package=faraway (accessed on 26 March 2020).

53. Imdad, M.U.; Aslam, M. Mctest: Multicollinearity Diagnostic Measures. Available online: https://CRAN.Rproject.org/package=mctest (accessed on 26 March 2020).

54. Imdad, M.U.; Aslam, M.; Altaf, S.; Ahmed, M. Some New Diagnostics of Multicollinearity in Linear Regression Model. Sains Malays. 2019, 48, 2051-2060. [CrossRef]

55. Imdadullah, M.; Aslam, M.; Altaf, S. Mctest: An R Package for detection of collinearity among regressors. R J. 2016, 8, 499-509. Available online: https://journal.r-project.org/archive/2016/RJ-2016-062/index.html (accessed on 26 March 2020). [CrossRef]

56. Unal, A.; Hu, Y.; Chang, M.E.; Odman, M.T.; Russell, A.G. Airport related emissions and impacts on air quality: Application to the Atlanta International Airport. Atm. Environ. 2005, 39, 5787-5798. [CrossRef]

57. Regulation of the Minister of the Environment. Regulation of the Minister of the Environment Dated 1 September 2016 on Procedures of Pollution Assessment for the Land Surface; (Republic of Poland, Journal of Laws of 2016, No. 1, Item 1395); The Minister of the Environment: Wawelska, Poland, 2016.

58. Mazaheri, M.; Bostrom, T.E.; Johnson, G.R.; Morawska, L. Composition and morphology of particle emissions from in-use aircraft during takeoff and landing. Environ. Sci. Technol. 2013, 47, 5235-5242. [CrossRef]

59. Turgut, E.T.; Gaga, E.O.; Jovanović, G.; Odabasi, M.; Artun, G.; Ari, A.; Urošević, M.A. Elemental characterization of general aviation aircraft emissions using moss bags. Environ. Sci. Poll. Res. 2019, 26, 26925-26938. [CrossRef]

60. Kesgin, U. Aircraft emissions at Turkish airports. Energy 2006, 31, 372-384. [CrossRef]

61. Skorupski, J. Airport operations safety assessment with the use of colored Petri nets. In Safety and Reliability of Complex Engineered Systems, Proceedings of the 25th European Safety and Reliability Conference, Zürich, Switzerland, 7-10 September 2015; CRC Press: Boca Raton, FL, USA; Taylor \& Francis: Abingdon, UK, 2015.

62. Boeing Okecie (Warsaw Frederic Chopin) Airport. The Boeing Company. 2020. Available online: http: //www.boeing.com/resources/boeingdotcom/commercial/noise/okecie.html (accessed on 18 May 2020).

63. Zhu, Y.; Fanning, E.; Yu, R.C.; Zhang, Q.; Froines, J.R. Aircraft emissions and local air quality impacts from takeoff activities at a large International Airport. Atm. Environ. 2011, 45, 6526-6533. [CrossRef]

64. He, R.W.; Shirmohammadi, F.; Gerlofs-Nijland, M.E.; Sioutas, C.; Cassee, F.R. Pro-inflammatory responses to PM0.25 from airport and urban traffic emissions. Sci. Total Environ. 2018, 640, 997-1003. [CrossRef]

65. Amato, F.; Moreno, T.; Pandolfi, M.; Querol, X.; Alastuey, A.; Delgado, A.; Pedrero, M.; Cots, N. Concentrations, sources and geochemistry of airborne particulate matter at a major European airport. J. Environ. Monit. 2010, 12, 854-862. [CrossRef]

66. Bennett, M.; Christie, S.M.; Graham, A.; Thomas, B.S.; Vishnyakov, V.; Morris, K.; Peters, D.M.; Jones, R.; Ansell, C. Composition of smoke generated by landing aircraft. Environ. Sci. Technol. 2011, 45, 3533-3538. [CrossRef] 
67. Valotto, G.; Zannoni, D.; Rampazzo, G.; Visin, F.; Formenton, G.; Gasparello, A. Characterization and preliminary risk assessment of road dust collected in Venice airport (Italy). J. Geochem. Exp. 2018, 190, 142-153. [CrossRef]

68. Mander, Ü.; Kull, A.; Frey, J. Residual Cadmium and Lead Pollution at a Former Soviet Military Airfield in Tartu, Estonia. In Biogeochemical Investigations of Terrestrial, Freshwater, and Wetland Ecosystems across the Globe; Wieder, R.K., Novák, M., Vile, M.A., Eds.; Springer: Berlin/Heidelberg, Germany, 2004.

69. Calijuri, M.L.; da Fonseca Santiago, A.; Neto, R.F.M.; de Castro Carvalho, I. Evaluation of the ability of a natural wetland to remove heavy metals generated by runways and other paved areas from an airport complex in Brazil. Water Air Soil Poll. 2011, 219, 319-327. [CrossRef]

70. Shahzad, B.; Tanveer, M.; Rehman, A.; Cheema, S.A.; Fahad, S.; Rehman, S.; Sharma, A. Nickel; whether toxic or essential for plants and environment-A review. Plant Phys. Biochem. 2018, 132, 641-651. [CrossRef]

71. Sreekanth, T.V.M.; Nagajyothi, P.C.; Lee, K.D.; Prasad, T.N.V.K.V. Occurrence, physiological responses and toxicity of nickel in plants. Int. J. Environ. Sci. Technol. 2013, 10, 1129-1140. [CrossRef]

72. Lawton, R.N.; Fujiwara, D. Living with aircraft noise: Airport proximity, aviation noise and subjective wellbeing in England. Transport. Res. D Trans. Environ. 2016, 42, 104-118. [CrossRef]

73. Postorino, M.N.; Mantecchini, L.A. systematic approach to assess the effectiveness of airport noise mitigation strategies. J. Air Trans. Manag. 2016, 50, 71-82. [CrossRef]

(C) 2020 by the authors. Licensee MDPI, Basel, Switzerland. This article is an open access article distributed under the terms and conditions of the Creative Commons Attribution (CC BY) license (http://creativecommons.org/licenses/by/4.0/). 